\title{
OXIDATION OF ORTHO AMINOBENZYL ALCOHOL: A CONCISE KINETIC STUDY
}

\author{
Manila $^{1}$, R.D. Kaushik ${ }^{2}$, Sandhya Sharma ${ }^{1, \bowtie}$, Jaspal Singh $^{2}$ and Neha Bhatt ${ }^{1}$ \\ ${ }^{1}$ Department of Chemistry, Kanya Gurukul Campus, Gurukul Kangri (Deemed to be University), \\ Haridwar, 249404, (Uttarakhand) India \\ ${ }^{2}$ Department of Chemistry, Gurukul Kangri (Deemed to be University), \\ Haridwar, 249404, (Uttarakhand) India \\ ${ }^{\otimes}$ Corresponding Author: sandhyavk18@gmail.com
}

\begin{abstract}
The foremost objective of the present work is to get a deep insight into the kinetics of ortho aminobenzyl alcohol (OABAlc) to develop a simple, efficient, and cost-effective method for its detection in contaminated water samples. This work deals with the silver catalyzed oxidation of OABAlc by potassium persulphate. The rate of oxidative reaction was determined by kinetic spectrophotometric method with absorption maxima of the reaction mixture at $440 \mathrm{~nm}$, at constant $\mathrm{pH}$ and temperature of the solution. The effect of substrate, oxidant, catalyst, $\mathrm{pH}$, temperature, ionic strength, and dielectric constant in this reaction has also been studied. During the investigation of thermodynamic parameters, the activation energy was found to be $58.92 \mathrm{~kJ} / \mathrm{mol}$, activation entropy $=-53.61$, activation enthalpy $=56.25 \mathrm{~kJ} / \mathrm{mol}$, and free energy $=73.43 \mathrm{~kJ} / \mathrm{mol}$. The results manifest first-order kinetics of the reaction concerning substrate, oxidant, and catalyst at optimum $\mathrm{pH} 7.0$ and $40^{\circ} \mathrm{C}$ temperature. To explore further application and importance of OABAlc, a study on various aspects of the oxidation reaction is carried out in the presence of $\mathrm{Ag}(\mathrm{I})$ as a catalyst and a strong oxidant potassium persulphate to get deep insight into the chemical aspects of the compound and to deduce the mechanism of reaction under study.

Keywords: Oxidation, Kinetics, Ortho Aminobenzyl alcohol, Potassium Persulphate, Silver Nitrate, Absorption Maxima, Thermodynamic Parameters.
\end{abstract}

RASĀYAN J. Chem., Special Issue, 2021

\section{INTRODUCTION}

The formation of aldehydes, ketones, and other nitrogen-based heterocycles from benzyl alcohols and their derivatives are known for their industrial importance. ${ }^{1-4}$ The carbonyl compounds so formed are absorbed in the synthesis of varied high-grade chemicals and agro-based products. ${ }^{5}$ The oxidation products of alcohols are widely used as a substrate in both research and industries due to its usage in various pharmaceutical preparations, which tends to be significant and versatile intermediates for the synthesis of new chemicals required to prepare soaps, perfumes, dyes, etc. ${ }^{6-9}$ Benzyl alcohol and its derivatives, particularly aminobenzyl alcohols have a wide range of applications in organic chemistry and drug synthesis. ${ }^{10}$ The mono-substituted benzyl alcohols and their derivative compounds, especially aminobenzyl alcohols, are a class of protean intermediates used in pharmaceutical and medicinal chemistry. OABAlc has vast synthetic applicability. They are naturally occurring alkaloids present in the leaves of plants with their traditional medicinal activities. ${ }^{11}$ Despite the above-mentioned applications, the toxicity of OABAlc towards humans and the environment cannot be overlooked. The harmful impact of OABAlc is characterized by serious skin allergy, headache, fatigue, dizziness, dyspnea, rapid heart rate, and blue-colored skin emanating from the lack of proper oxygenation in blood and ultimately leading to death. ${ }^{12}$ OABAlc and its derivatives might become a part of the wastewater streams originating from pharmaceuticals manufacturing units that are involved in the production or usage of OABAlc ${ }^{13-16}$ eventually turning detrimental to flora and fauna of the environment in a general and aquatic ecosystem in specific.

In this regard, many traditional methods have been reported on the selective oxidation of aminobenzyl alcohols, these reactions are synthetically advantageous, but they require aggressive reaction conditions, 
RASĀYAN J. Chem.

98-109| Special Issue | 2021

use of stoichiometric reagents, difficulties in workup procedures and are also prone to undergo over oxidation.

The production of amino carbonyl derivatives from their respective OABAlc remains a daunting task and their methodologies are not widely investigated owing to the reaction between oxidant and amino groups that leads to a substantial decrease in the yield of a viable product. Therefore, it is still extremely desirable and stimulates us further to form practical catalytic systems for the alcohol oxidation without affecting the other oxidizable functional groups like amino, alkyne, and hydroxyl, etc., under normal reaction conditions.

To investigate the behavior of OABAlc, the Indirect Friedlander method has been documented in which OABAlc has been reacted with ketones catalyzed by transition-metal complexes obtained from ruthenium, ${ }^{17-19}$ palladium, ${ }^{20}$ iridium, ${ }^{21}, 22$ rhodium, ${ }^{23}$ and copper. ${ }^{24}$ Different methods have been developed from time to time, making use of transition metals viz: manganese, cobalt, nickel, iron ${ }^{25}$ iodine reagents, etc. Various advanced oxidation processes (AOPs) and in-situ chemical oxidation (ISCO), have been applied to quickly oxidize the broad range of pharmaceuticals from wastewaters and soil samples. ${ }^{26,27}$ Many other oxidants are used to remove contaminants, including hydrogen peroxide $\left(\mathrm{H}_{2} \mathrm{O}_{2}\right)$, permanganate $\left(\mathrm{MnO}_{4}{ }^{-}\right)$, persulphate, ozone $\left(\mathrm{O}_{3}\right)$, and Fenton process $(\cdot \mathrm{OH} \cdot)$. Among all of these oxidants, both persulphate salt such as PDS and PMS has good performance in wastewater treatment to oxidize the contaminants present in water samples. On the other hand, PDS has accrued attention due to its conjoint properties (i.e., hydrogen peroxide, ozone) in the ISCO technique to transform groundwater adulterants into less toxic chemical species.

Potassium persulphate has also emerged as a strong oxidant for oxidizing environmental contaminants into less toxic species. It is also known as potassium peroxydisulphate or KPS. It is also found to be efficacious in degrading organic pollutants, particularly for the aromatic pollutants category. It is known to be the best choice due to its low cost and easy availability. Persulphate ions are outstanding and multiskilled oxidizing agents used mainly for oxidation of synthetic, natural, organic, and inorganic substances in aqueous and neutral solutions and are also used for polymerization. In photo-oxidative removal of some organic compounds gives the best results in comparison to other persulphate salts under natural $\mathrm{pH}$. It dissociates into the water by forming sulphate anion, which shows slow rate kinetics of organic pollutants. Therefore, to increase the rate of reaction, many transition metal catalysts i.e., $\mathrm{Fe}, \mathrm{Ag}$, $\mathrm{Cu}, \mathrm{Zn}, \mathrm{Mn}$, and $\mathrm{Ti}$ are known to activate this oxidant to generate sulphate radicals $\left(\mathrm{SO}_{4^{-}}\right)$, facilitating through one-electron transfer process ${ }^{28}$ and potassium persulphate can also be activated by thermally and photo-chemically activation processes to generate these sulfate radicals for progressing the chemical reaction systemically. In some cases, it has been documented in the literature that $\mathrm{Ag}$ (I) produces $\mathrm{Ag}$ (II), sulfate radical anion, and sulfate anion with the combination of potassium persulphate. The sulphate radicals so generated react freely with a broad range of organic contaminants present in groundwater and soils to give rise to additional reactive species like hydroxyl radicals, hydrogen peroxide, etc., which are important degradation processes for various pollutants present in water and soils. ${ }^{29}$

In our present work, we used potassium persulphate as an oxidizing agent because of its low cost, ease in its availability, and simple handling to oxidize OABAlc. The oxidation of alcohols by this oxidant shows slow rate kinetics. To overcome this problem, $\mathrm{Ag}(\mathrm{I})$ in the form of $\mathrm{AgNO}_{3}$ has been used as a catalyst to activate Potassium persulphate under neutral $\mathrm{pH}$.

The main purpose of this work was the investigation of the oxidation of OABAlc to analyze the kinetic and thermodynamic behavior of reaction under normal reaction conditions. This method was carried out in simple operational conditions and found to be eco-friendly in all conditions.

\section{Material and Methods}

\section{EXPERIMENTAL}

Reagent grade OABAlc was purchased from Sigma Aldrich chemicals and its solution was prepared in acetone. Potassium persulphate and Ag (I) (Merck, India) were used and the solution was prepared in triply distilled water. Ammonium nitrate and ammonium hydroxide were used to make a buffer for running the kinetic experiments. The reaction mixture is formed by the addition of potassium persulphate solution, OABAlc, buffer, and catalyst. The kinetic reaction was studied in ammonia buffer with almost 
RASĀYAN J. Chem.

98-109| Special Issue | 2021

stable $\mathrm{pH}$ during the entire process. For this above process, a buffer made from ammonium nitrate and ammonium hydroxide was used for obtaining the desired $\mathrm{pH}$.

\section{Buffer Preparation}

Ammonia buffer was prepared using the previously reported method. For this preparation, $1 \mathrm{M}$ of ammonium nitrate and $1 \mathrm{M}$ of ammonium hydroxide were used for the kinetic experiment. To run the experiments, the ammonium nitrate was dissolved in triply distilled water in a $250 \mathrm{ml}$ volumetric flask. Then standardize the ammonium nitrate solution with ammonium hydroxide to set the $\mathrm{pH}$ of the reaction mixture by using SYSTRONICS- Digital pH meter-335.

\section{Preliminary Investigation}

When the reactants were mixed, the solution turned light yellow initially changing to dark color later on. It finally gives the product on keeping for a longer time duration. Surprisingly, when we kept the reaction mixture at room temperature, the silver mirror formation was observed on the inner surface of the Erlenmeyer flask, which was further confirmed by using tollens reagent (silver mirror on the test tube) as a preliminary investigation in the laboratory. The silver mirror on the flask indicates the presence of aminobenzaldehyde in the reaction mixture as a reaction intermediate. The absorption maxima of the reaction mixtures are in the visible region, while the UV-VIS spectra of potassium persulphate and Ag (I) indicate no absorption in the visible region. The absorbance of the sample was recorded as a function of time. The kinetic experiments were carried out at temperature regulation of reaction mixture in a thermostat water bath with a precision of $\pm 0.1^{\circ} \mathrm{C}$. The kinetics of $\mathrm{Ag}$ (I) catalyzed, the oxidation reaction of OABAlc was studied in basic buffer at $\mathrm{pH} 7.0$ and temperature $40^{\circ} \mathrm{C}$. Under all the conditions and concentrations, the reaction showed first-order dependence concerning substrate, oxidant, and catalyst.

\section{Kinetic Experiments for Ag (I) catalysed Oxidation of OABAlc with Potassium Persulphate}

The reaction mixture was prepared for the determination of absorption maxima to analyze the order concerning substrate, oxidant, and catalyst. The impact of different parameters like ionic strength, $\mathrm{pH}$, dielectric constant, and temperature was also observed.

The order of reaction was determined w.r.t. OABAlc and the rate of reaction was studied by varying it in the concentration range $1.0 \times 10^{-2}$ to $2.5 \times 10^{-2} \mathrm{M}$ for which the amount of oxidizing agent was kept the same, i.e., $1.0 \times 10^{-3} \mathrm{M}$ with constant $\mathrm{pH}$ and temperature, in ammonia buffer medium. In the variation of OABAlc, the reaction kinetics was found of the first-order. The rate of reaction was calculated by the plane mirror method and the value of $k_{o b s}$ was calculated from Guggenheim method. ${ }^{30}$ The graph plotted by the Guggenheim method was found to be linear with a negative slope.

To determine the order concerning oxidant, the rate of reaction on the variation of the oxidant was studied by varying it in the concentration range $4.0 \times 10^{-3}$ to $5.5 \times 10^{-3} \mathrm{M}$ with the substrate being constant i.e. 4.0 $\times 10^{-4}$ at constant $\mathrm{pH}$ and temperature. In the variation of oxidant, the kinetics of the reaction was found to follow the first-order.

To find the impact of variation of catalyst, the rate of reaction on the variation of $\mathrm{Ag}$ (I) was studied by varying it in the concentration range of $3.0 \times 10^{-4}$ to $6.0 \times 10^{-4} \mathrm{M}$ in which concentration of substrate and oxidant was kept constant with fixed $\mathrm{pH}$ and temperature. Kinetics of reaction was observed to follow first-order concerning $\mathrm{Ag}$ (I) on studying the variation of $\mathrm{Ag}$ (I).

The temperature effect on the rate of oxidation of OABAlc was studied in the range of 40 to $55^{\circ} \mathrm{C}$. OABAlc, Ag (I), and oxidant were kept at $4.0 \times 10^{-4} \mathrm{M}, 3.0 \times 10^{-4} \mathrm{M}$, and $4.0 \times 10^{-3} \mathrm{M}$ respectively. The data so drawn was used to calculate the thermodynamic parameters associated with the reaction under study.

For further investigation of the solvent interactions on the rate of reaction, acetone was used as a reaction solvent which acts as a binary mixture with water in the reaction mixture. In this experiment, the substrate was kept at $4.0 \times 10^{-4} \mathrm{M}$, catalyst at $3.0 \times 10^{-4} \mathrm{M}$, and oxidant at $5.0 \times 10^{-3} \mathrm{M}$ while keeping other conditions unchanged. The amount of acetone was varied from a range of 4 to $16 \%$ to determine the results.

To examine the effect of ionic strength $\mathrm{NaNO}_{3}$ (sodium nitrate) was used as ionic salt, which determines the ionic strength of the reaction mixture. In this kinetic run, the concentration of OABAlc, catalyst, and 
RASĀYAN J. Chem.

98-109| Special Issue | 2021

oxidant was $4.0 \times 10^{-4} \mathrm{M}, 3.0 \times 10^{-4} \mathrm{M}$, and $5.5 \times 10^{-3} \mathrm{M}$, respectively. The $\mathrm{Na}^{+}$ions were taken from its nitrate part and the concentration of $\mathrm{NaNO}_{3}$ ions was altered in between $2.0 \times 10^{-3}$ to $8.0 \times 10^{-3} \mathrm{M}$.

\section{Formulae used to calculate the Thermodynamic Parameters for Kinetics of Oxidation Reaction}

To investigate the thermodynamic parameter of reaction, different methods were used, which are as follows. In 1989, Arrhenius suggested a simple reaction relation between the rate of reaction and the temperature of the reaction. Arrhenius equation was used to calculate the effect of change of temperature on the rate constant and the reaction rate as well. We plotted the graph between $\log k_{\text {cat }}$ and $1 / \mathrm{T}$ to show the effect of temperature on reaction rate constant which follows the Arrhenius equation:

$\log k_{\text {cat }}=[-E a / 2.303 R T]+$ Constant

Where, $\mathrm{Ea}=$ the activation energy in $\mathrm{kJ} / \mathrm{mol}, \mathrm{R}=\mathrm{Gas}$ constant $\left(1.987 \times 10^{-3}\right), \mathrm{T}=$ temperature of reaction.

The activation energy $\left(\mathrm{E}_{\mathrm{a}}\right)$ was calculated by the following formula:

$$
E_{a}=2.303 R \frac{\left[T_{1} \times T_{2}\right]}{\left[T_{2}-T_{1}\right]} \times \log \left[\left(k_{\text {cat }}^{\prime \prime}\right) /\left(k_{\text {cat }}^{\prime}\right)\right]
$$

Where, $k_{c a t}^{\prime}$ and $k_{c a t}^{\prime \prime}$ were calculated overall rate constants at temperature $\mathrm{T}_{1}$ and $\mathrm{T}_{2}$, respectively.

Other thermodynamic parameters were given below.

Frequency factor (A) in $\mathrm{dm}^{3} / \mathrm{mol}-\mathrm{s}$ was calculated by the following formula:

$$
k_{c a t}=A \cdot e^{\left(-E_{a} / R T\right)}
$$

Free energy of activation $\left(\Delta \mathrm{F}^{\#}\right)$ in $\mathrm{kJ} / \mathrm{mol}$ was calculated by the following formula:

$\Delta F^{\#}=\Delta H^{\#}-\left(T \Delta S^{\#}\right) \times 10^{-3}$

Enthalpy of activation $\left(\Delta \mathrm{H}^{\#}\right)$ in $\mathrm{kJ} / \mathrm{mol}$ was calculated by the following formula:

$\Delta H^{\#}=E_{a}-R T$

Where, $\mathrm{E}_{\mathrm{a}}=$ activation energy, $\mathrm{T}=$ Temperature, $\mathrm{R}=1.987 \times 10^{-3}$.

The entropy of activation $\left(\Delta \mathrm{S}^{\#}\right)$ in $\mathrm{J} / \mathrm{k}$-mol was calculated by the following formula:

$k_{c a t}=\left(k_{b} T / h\right) \cdot e^{\left(-E_{a} / R T\right)} \cdot e^{(\Delta S / R)}$

Where, $\mathrm{k}_{\mathrm{b}}=$ Boltzmann constant and $\mathrm{h}=$ Planck's constant.

Formulae used to Calculate the Value of Rate Constant and Overall Rate Constant

Rate constant $\left(k_{o b s}\right)$ - The value of $k_{o b s}$ was calculated by the following formula:

$k_{\text {obs }}=\left[\left(A_{2}-A_{1}\right) /\left(T_{2}-T_{1}\right)\right] \times 2.303$

Where $\mathrm{A}=$ Absorbance and $\mathrm{T}=$ temperature of reaction sample.

The overall rate constant $\left(k_{c a t}\right)$ - the value of $k_{c a t}$ was calculated by the following formula:

$$
k_{c a t}=k_{o b s} / \text { [highest concentration of set } \times \text { catalyst concentration] }
$$

\section{UV-VIS Analysis}

\section{RESULTS AND DISCUSSION}

A reaction mixture was prepared in an iodine flask to determine the absorption maxima of the reaction mixture at different conditions and concentrations. The absorbance of the sample was recorded on a UVVIS Double Beam Spectrophotometer-2203 as a function of time by plotting the graph to find out the $\lambda_{\max }$ of the reaction mixture. During the investigation of $\lambda_{\max }$ of the reaction mixture, it was found to be 440 $\mathrm{nm}$. The graph for $\lambda_{\max }$ of reaction sample was plotted between absorbance and wavelength with time is shown in Fig.-1.

\section{FT-IR (Fourier Transform Infrared) Spectroscopy to Identify the Product}

FT-IR is a technique used to characterize different functional groups, molecules, and gases present in a reaction mixture by scanning the sample between the frequency ranges from $4000-400 / \mathrm{cm}$. 
RASĀYAN J. Chem.

98-109| Special Issue | 2021

The absorption peaks in FTIR spectra was 3500.0, 3213.0, 2745.0, 2397.0, 1689.55, 1408.5, 1382.3, $1347.3,1082.2,830.6,618.9,452.9 / \mathrm{cm}$ compared with literature data. In this analysis, the peaks at $2745.0 / \mathrm{cm}$ frequency for $\mathrm{C}-\mathrm{H}$ and $1689.55 / \mathrm{cm}$ for $\mathrm{C}=\mathrm{O}$ with stretching frequency indicates the existence of -CHO (aldehyde) group in the reaction sample. The peak 3213.0 and $3500.0 / \mathrm{cm}$ is for N-H and 1082.2 /cm with C-N Stretching frequency signifies amino $\left(-\mathrm{NH}_{2}\right)$ group was also present. The functional groups like $-\mathrm{CHO}$ and $-\mathrm{NH}_{2}$ confirm the presence of ortho aminobenzaldehyde in the reaction mixture as a reaction product.

Whereas other peaks like 2397.0/cm show $\mathrm{O}=\mathrm{C}=\mathrm{O}$ stretching for $\mathrm{CO}_{2}$, and 1408.5 with $\mathrm{O}-\mathrm{H}$ bending indicates $-\mathrm{COOH}$ (carboxylic acid) group, and a peak at 1347.3 was observed with $\mathrm{O}-\mathrm{H}$ stretching which indicates - $\mathrm{OH}$ group was also found to be present in the sample. The FTIR data of the product is shown in Fig.-2.

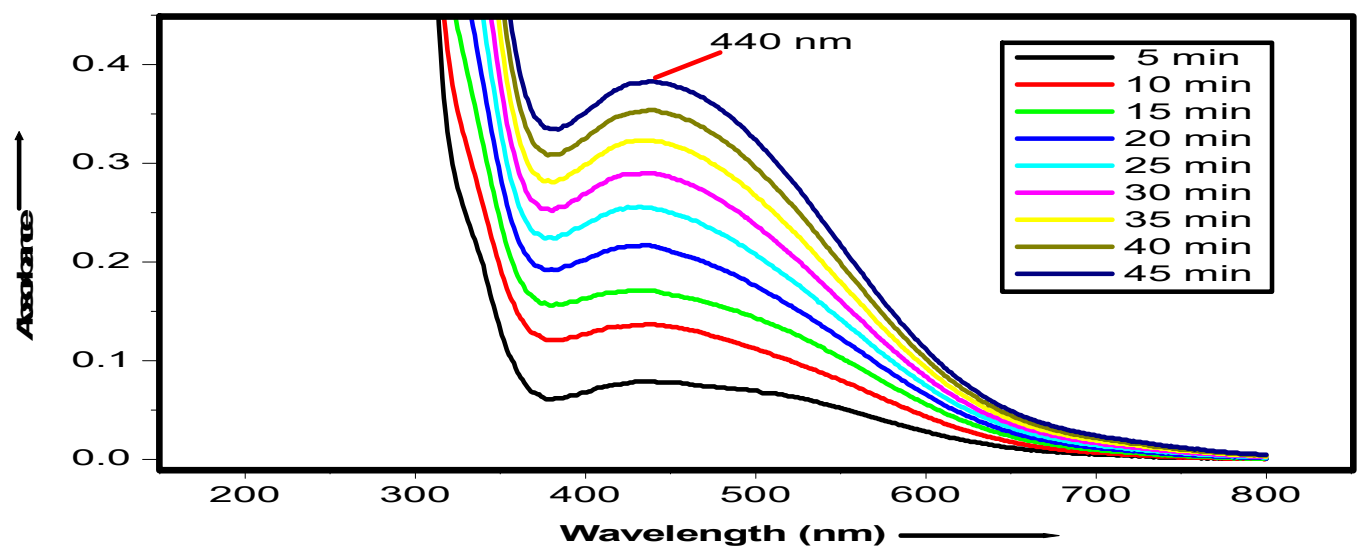

Fig.-1: UV-VIS Absorption Spectra of Ag (I) catalyzed Oxidation of OABAlc with Potassium Persulphate. Conditions: $[\mathrm{OABAlc}] \times 10^{4}=4.0 \mathrm{M},[\mathrm{KPS}] \times 10^{3}=5.0 \mathrm{M},[\mathrm{Ag}(\mathrm{I})] \times 10^{4}=3.0 \mathrm{M}, \mathrm{Temp}=40 \pm 0.1^{0} \mathrm{C}, \mathrm{pH}=7.0, \lambda_{\max }$ $=440 \mathrm{~nm}$

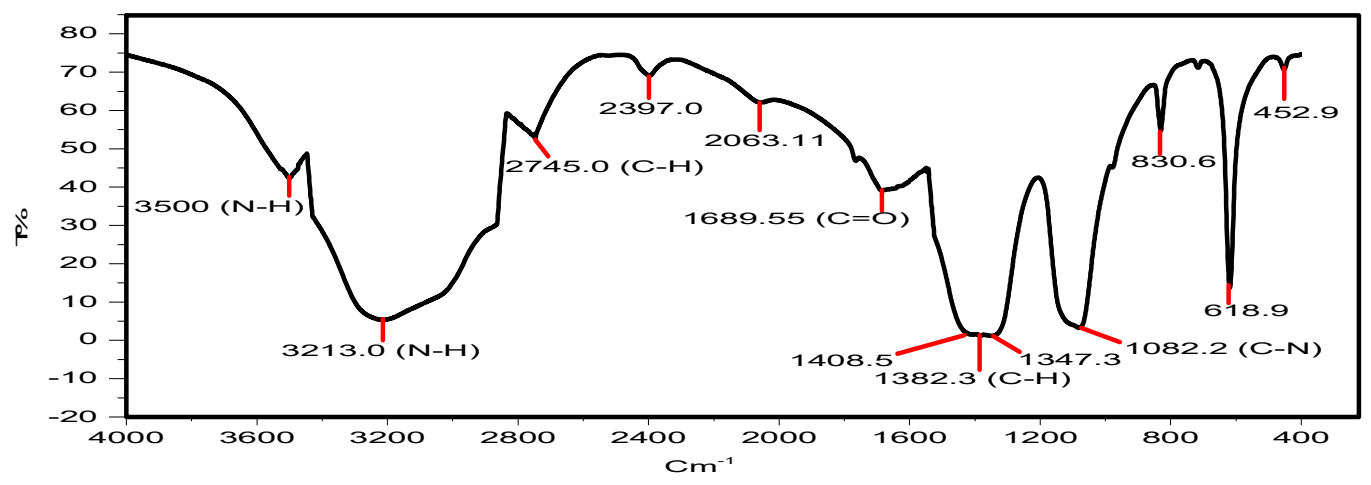

Fig.-2: FT-IR Spectrum of Ag (I) catalyzed Oxidation of OABAlc with Potassium Persulphate

\section{Order of Reaction in Case of Substrate, Oxidant, and Catalyst}

After analyzing the variation of a substrate, it can be concluded that there is an increase in the rate of reaction with the incremental concentration of substrate (OABAlc>oxidant) and all other constituents and conditions remain constant during the variation, as shown in Fig.-3. On plotting the graph between the rate of reaction $(\mathrm{dA} / \mathrm{dt})$ and concentration of OABAlc, the slope comes out to be linear, which indicates first-order reaction with a value of $\mathrm{n}_{1}$ was 1.0 as shown in Fig.-4. Similarly, during the variation of oxidant, an increased rate of reaction is seen on surging the concentration of oxidant [OABAlc $<$ oxidant] as shown in Fig.-5. Graphical representation between the rate of reaction and concentration of oxidant shows a linear plot which implies the first-order reaction concerning oxidant with a value of $n_{2}$ was 1.07 as shown in Fig.-6. In the case of variation of catalyst, the rate of reaction increases with an increase in 
RASĀYAN J. Chem.

98-109| Special Issue | 2021

the concentration of catalyst as shown in Fig.-7. Graph plotted between the rate of reaction and concentration of $\mathrm{Ag}(\mathrm{I})$ shows a straight line and value of $\mathrm{n}_{3}=1.0$, which indicates the first-order reaction concerning catalyst also as shown in Fig.-8. Where, $\mathrm{n}_{1}, \mathrm{n}_{2}$, and $\mathrm{n}_{3}$ are the order of reaction, respectively. The order of reaction (n) was calculated by using the following formula:

$n=\frac{\log \left[(d A / d t)_{\mathrm{i}}\right]_{1}-\log \left[(d A / d t)_{i}\right]_{2}}{\log { }_{1}-\log C_{2}}$

Where $\mathrm{n}=$ order of reaction, $\left[(\mathrm{dA} / \mathrm{dt})_{\mathrm{i}}\right]_{1}$ and $\left[(\mathrm{dA} / \mathrm{dt})_{\mathrm{i}}\right]_{2}$ was initial rates of reaction corresponding to initial concentrations $\mathrm{C}_{1}$ and $\mathrm{C}_{2}$ of reactant. A concise detail of the experimental data of different kinetic experiments has been tabulated in Table-1.

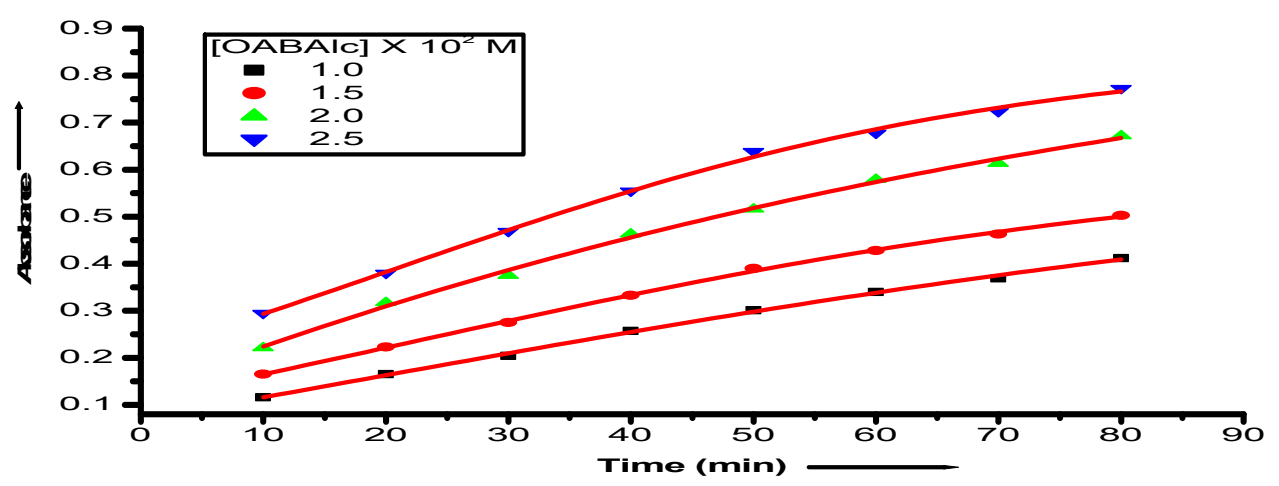

Fig.-3: Variation of OABAlc (Absorbance Vs Time Plot)

Conditions: $[\mathrm{KPS}] \times 10^{3}=1.0 \mathrm{M},[\mathrm{Ag}(\mathrm{I})] \times 10^{4}=3.0 \mathrm{M}, \mathrm{Temp}=40 \pm 0.1^{\circ} \mathrm{C}, \mathrm{pH}=7.0, \lambda_{\max }=440 \mathrm{~nm}$

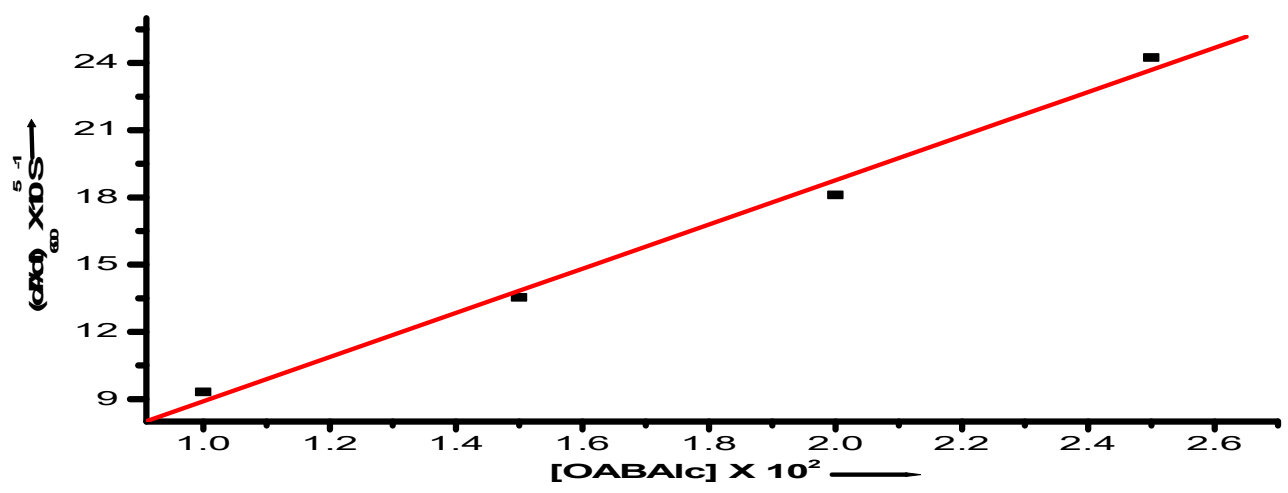

Fig.-4: Determination of Order with respect to OABAlc.

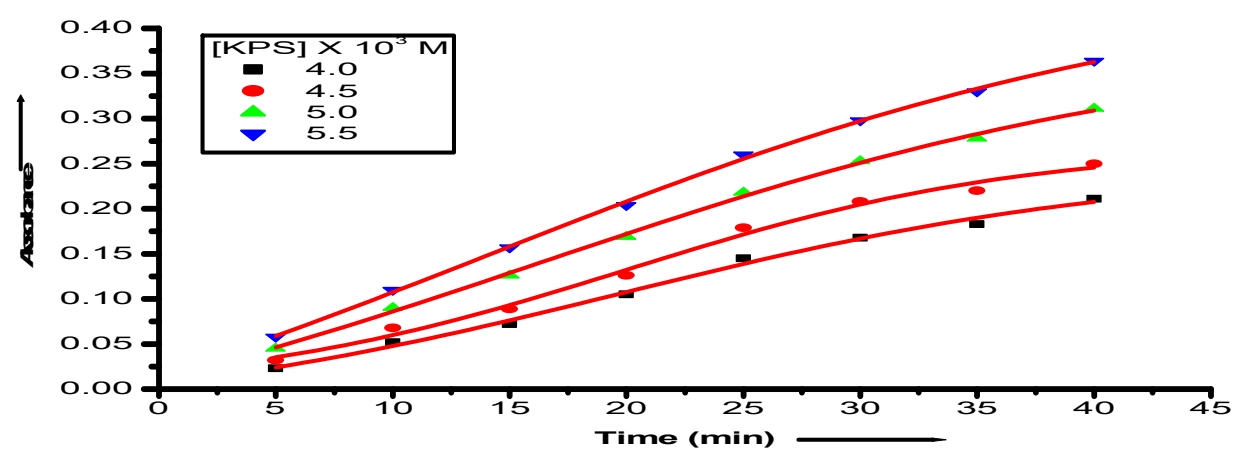

Fig.-5: Variation of Oxidant (Absorbance Vs Time plots)

Conditions: $[\mathrm{OABAlc}] \times 10^{4}=4.0 \mathrm{M},[\mathrm{Ag}(\mathrm{I})] \times 10^{4}=3.0 \mathrm{M}, \mathrm{Temp}=40 \pm 0.1^{\circ} \mathrm{C}, \mathrm{pH}=7.0, \lambda_{\max }=440 \mathrm{~nm}$. 
RASĀYAN J. Chem.

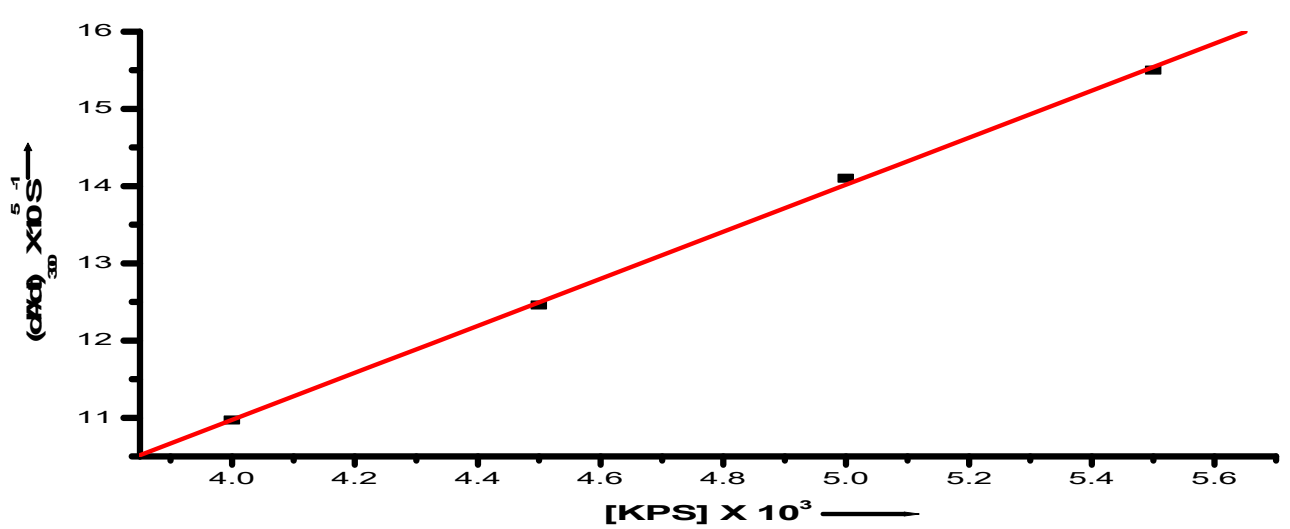

Fig.-6: Determination of Order with respect to Oxidant

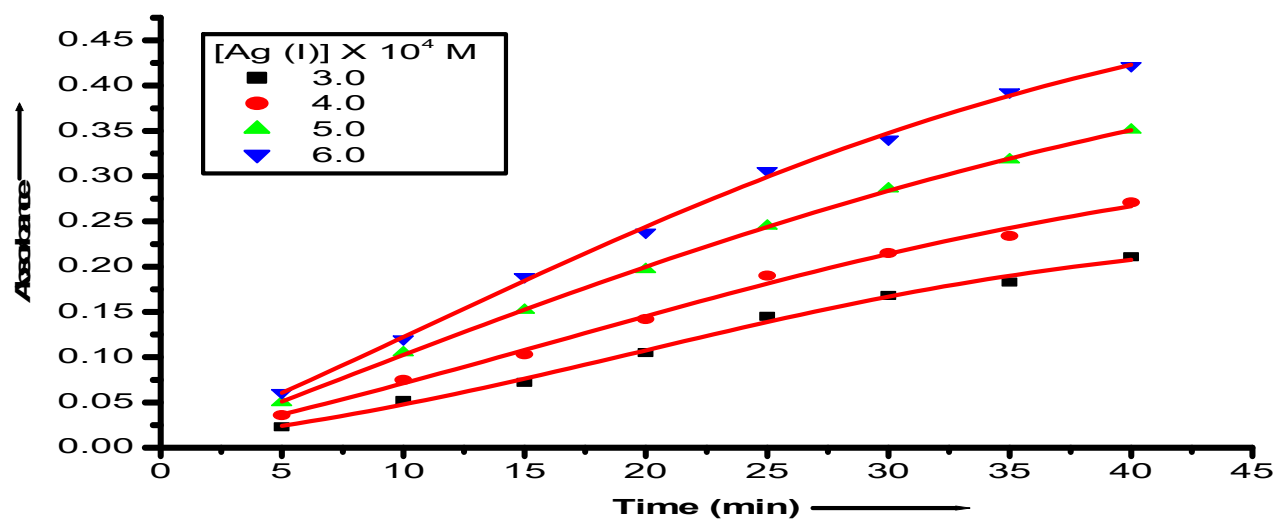

Fig.-7: Variation of Catalyst (Absorbance Vs Time Plot)

Conditions: $[\mathrm{OABAlc}] \times 10^{4}=4.0 \mathrm{M},[\mathrm{KPS}] \times 10^{3}=4.0 \mathrm{M}, \mathrm{pH}=7.0, \mathrm{Temp}=40 \pm 0.1^{0} \mathrm{C}, \lambda_{\max }=440 \mathrm{~nm}$

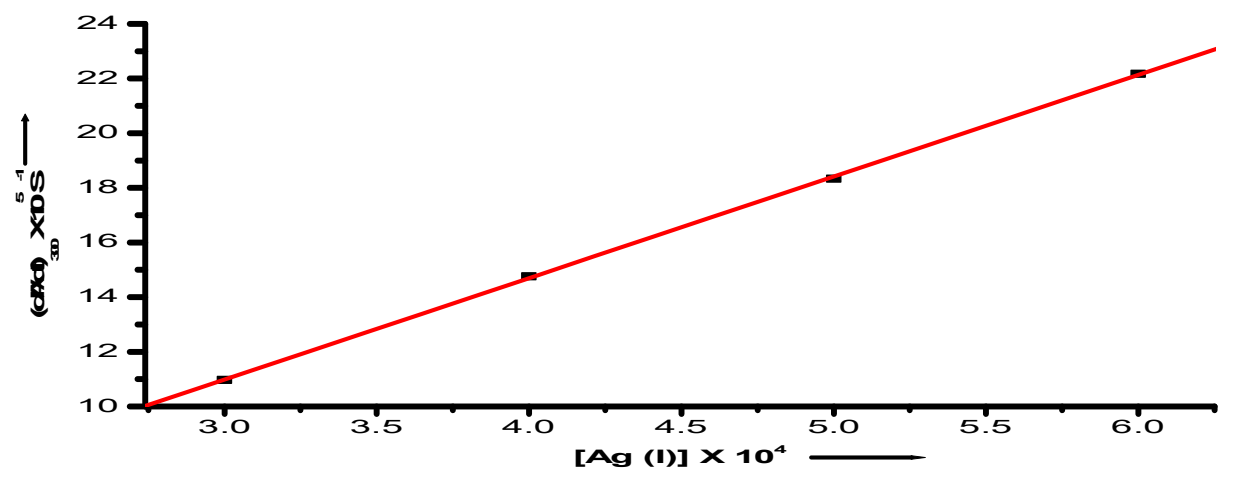

Fig.-8: Determination of Order with respect to the Catalyst

\section{Effect of pH on Reaction Rate}

The effect of $\mathrm{pH}$ is graphically shown in Fig.-9. It was carried out from $\mathrm{pH}$ range 6.5 to 9.5. The variation of $\mathrm{pH}$ was studied by keeping the concentration of ammonium nitrate fixed and varying the ammonium hydroxide solution. It has been observed that the rate of reaction was found to be maximum at $\mathrm{pH} 7.5$ whereas an increase in the $\mathrm{pH}$ results in the decrease of the rate of reaction. ${ }^{31}$ Rate constant and rate attained its maximum value as the $\mathrm{pH}$ approaches 7.5. Subsequently above $\mathrm{pH} 7.5$, the rate and rate constant of reaction decreases continuously. Above this $\mathrm{pH}$, ionization of persulphate salt must be at its maximum level, and thus, its sulphate ions completely dissociate into solution losing their stability, and hence, the decreased rate and rate constant was observed. Thus, it was concluded that oxidation of 
RASĀYAN J. Chem.

98-109| Special Issue | 2021

OABAlc by Potassium Persulphate shows the best kinetics and highest level of oxidation either in a slightly basic or in a neutral medium in our present analysis.

Table-1: Kinetic Data for Silver catalysed Oxidation of OABAlc by Potassium Persulphate

\begin{tabular}{c|c|c|c|c|c|c|c|c}
\hline $\begin{array}{c}\text { No. of } \\
\text { Exp. }\end{array}$ & $\begin{array}{c}{[\mathrm{KPS}] \times} \\
10^{3} \\
\left(\mathrm{~mol} / \mathrm{dm}^{3}\right)\end{array}$ & $\begin{array}{c}{[\mathrm{OABAlc}]} \\
\times \\
10^{3} \\
\left(\mathrm{~mol} / \mathrm{dm}^{3}\right)\end{array}$ & $\begin{array}{l}{[\mathrm{Ag}(\mathrm{I})]} \\
\times 10^{3} \\
(\mathrm{~mol} / \mathrm{d} \\
\left.\mathrm{m}^{3}\right)\end{array}$ & $\begin{array}{c}\mathrm{pH} \\
\end{array}$ & $\begin{array}{c}\text { Aceton } \\
\% \\
(\mathrm{~V} / \mathrm{V})\end{array}$ & $\begin{array}{c}{\left[\mathrm{NaNO}_{3}\right] \times} \\
10^{3}(\mathrm{~W} / \mathrm{V})\end{array}$ & $\begin{array}{c}10^{4} \\
k_{\text {obs }} / \mathrm{sec}\end{array}$ & $\begin{array}{c}k_{\text {cat }} \times 10^{-2} \\
\mathrm{dm}^{6} \mathrm{~mol}^{-} \\
2 / \mathrm{sec}\end{array}$ \\
\hline 1 & 1.0 & 10.0 & 0.30 & 7.0 & - & - & & \\
\hline 2 & 1.0 & 15.0 & 0.30 & 7.0 & - & - & 1.02 & 0.34 \\
\hline 3 & 1.0 & 20.0 & 0.30 & 7.0 & - & - & 2.05 & 0.34 \\
\hline 4 & 1.0 & 25.0 & 0.30 & 7.0 & - & - & 2.66 & 0.34 \\
\hline 5 & 4.0 & 0.40 & 0.30 & 7.0 & - & - & 1.62 & 1.35 \\
\hline 6 & 4.5 & 0.40 & 0.30 & 7.0 & - & - & 2.03 & 1.50 \\
\hline 7 & 5.0 & 0.40 & 0.30 & 7.0 & - & - & 2.32 & 1.55 \\
\hline 8 & 5.5 & 0.40 & 0.30 & 7.0 & - & - & 2.66 & 1.61 \\
\hline 9 & 4.0 & 0.40 & 0.30 & 7.0 & - & - & 1.62 & 1.35 \\
\hline 10 & 4.0 & 0.40 & 0.40 & 7.0 & - & - & 2.17 & 1.36 \\
\hline 11 & 4.0 & 0.40 & 0.50 & 7.0 & - & - & 2.65 & 1.33 \\
\hline 12 & 4.0 & 0.40 & 0.60 & 7.0 & - & - & 3.29 & 1.37 \\
\hline 13 & 5.0 & 0.40 & 0.30 & 7.0 & 4 & - & 2.32 & 1.55 \\
\hline 14 & 5.0 & 0.40 & 0.30 & 7.0 & 8 & - & 2.19 & 1.46 \\
\hline 15 & 5.0 & 0.40 & 0.30 & 7.0 & 12 & - & 2.04 & 1.36 \\
\hline 16 & 5.0 & 0.40 & 0.30 & 7.0 & 16 & - & 1.92 & 1.28 \\
\hline 17 & 5.5 & 0.40 & 0.30 & 7.0 & - & 2.0 & 2.51 & 1.52 \\
\hline 18 & 5.5 & 0.40 & 0.30 & 7.0 & - & 4.0 & 2.44 & 1.48 \\
\hline 19 & 5.5 & 0.40 & 0.30 & 7.0 & - & 6.0 & 2.37 & 1.44 \\
\hline 20 & 5.5 & 0.40 & 0.30 & 7.0 & - & 8.0 & 2.33 & 1.41 \\
\hline 21 & 4.0 & 0.40 & 0.30 & 7.0 & - & - & 1.62 & 1.35 \\
\hline 22 & 4.0 & 0.40 & 0.30 & 7.0 & - & - & 2.34 & 1.95 \\
\hline 23 & 4.0 & 0.40 & 0.30 & 7.0 & - & - & 3.30 & 2.75 \\
\hline 24 & 4.0 & 0.40 & 0.30 & 7.0 & - & - & 4.55 & 3.79 \\
\hline 25 & 5.5 & 0.40 & 0.30 & 6.5 & - & - & 2.37 & 1.44 \\
\hline 26 & 5.5 & 0.40 & 0.30 & 7.0 & - & - & 2.66 & 1.61 \\
\hline 27 & 5.5 & 0.40 & 0.30 & 7.5 & - & - & 2.83 & 1.72 \\
\hline 28 & 5.5 & 0.40 & 0.30 & 8.0 & - & - & 2.58 & 1.56 \\
\hline 29 & 5.5 & 0.40 & 0.30 & 8.5 & - & - & 2.33 & 1.41 \\
\hline 30 & 5.5 & 0.40 & 0.30 & 9.0 & - & - & 2.30 & 1.40 \\
\hline 31 & 5.5 & 0.40 & 0.30 & 9.5 & - & - & 2.22 & 1.35 \\
\hline & & & & & & & & \\
\hline
\end{tabular}

\section{Variation of Ionic Strength}

The influence of ionic strength was studied by using sodium nitrate $\left(\mathrm{NaNO}_{3}\right)^{32}$ as ionic salt with a concentration range from $2.0 \times 10^{-3}$ to $8.0 \times 10^{-3} \mathrm{M}$ by keeping fixed concentrations of other reaction ingredients at $\mathrm{pH} 7.0$ and $40^{\circ} \mathrm{C}$. The rate of reaction decreases with an increase in ionic strength. The plot between $\log k_{c a t}$ and ionic strength $(\mu)$ is found to be linear with a negative slope which indicates that the rate-determining step is a reaction between ion and dipole. The graph plotted between $\log k_{c a t}$ and ionic strength $(\mu)$ of the reaction mixture is represented in Fig.-10. The ionic strength of the reaction mixture is calculated by the following formula:

$$
\text { Ionic strength }(\mu)=\frac{1}{2} \times \sum\left(C_{i} Z_{i}^{2}\right)
$$

Where $\mu=$ ionic strength, $\mathrm{C}_{\mathrm{i}}=$ concentration of $\mathrm{Na}$ and $\mathrm{NO}_{3}$ ions, $\mathrm{Z}_{\mathrm{i}}=$ charge on ions. 
RASĀYAN J. Chem.

98-109| Special Issue | 2021

\section{Effect of Dielectric Constant}

The reaction mixtures act as a binary mixture due to the presence of water and acetone together. During the effect of acetone on the reaction mixture, the rate of reaction decreases as the amount of acetone increases. ${ }^{33}$

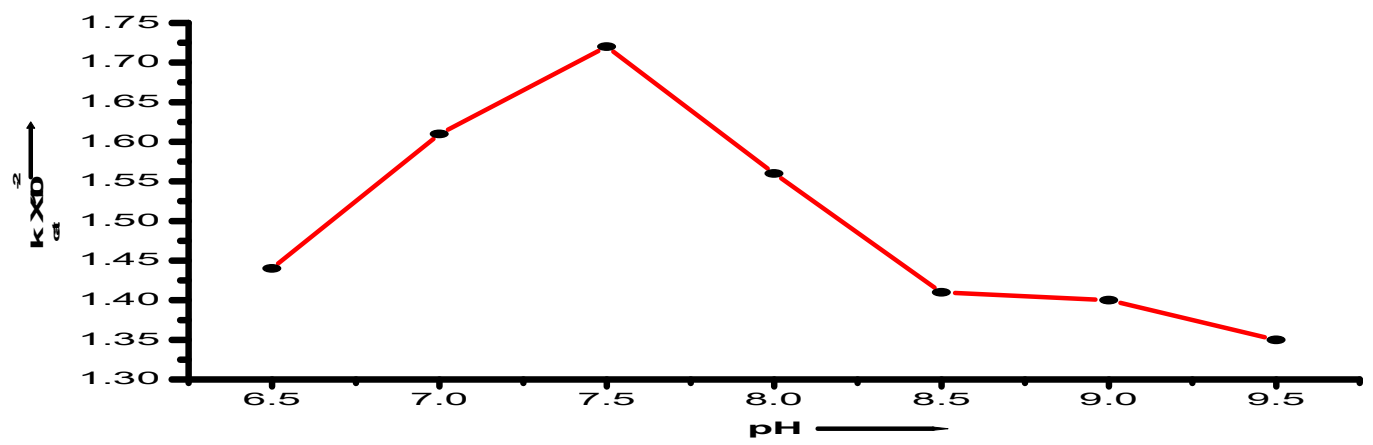

Fig.-9: Variation of $\mathrm{pH}\left(k_{c a t} \mathrm{Vs} \mathrm{pH}\right.$ plot $)$

Conditions: $[\mathrm{OABAlc}] \times 10^{4}=4.0 \mathrm{M},[\mathrm{KPS}] \times 10^{3}=5.5 \mathrm{M},[\mathrm{Ag}(\mathrm{I})] \times 10^{4}=3.0 \mathrm{M}, \mathrm{Temp}=40 \pm 0.1^{0} \mathrm{C}, \lambda_{\max }=440 \mathrm{~nm}$.

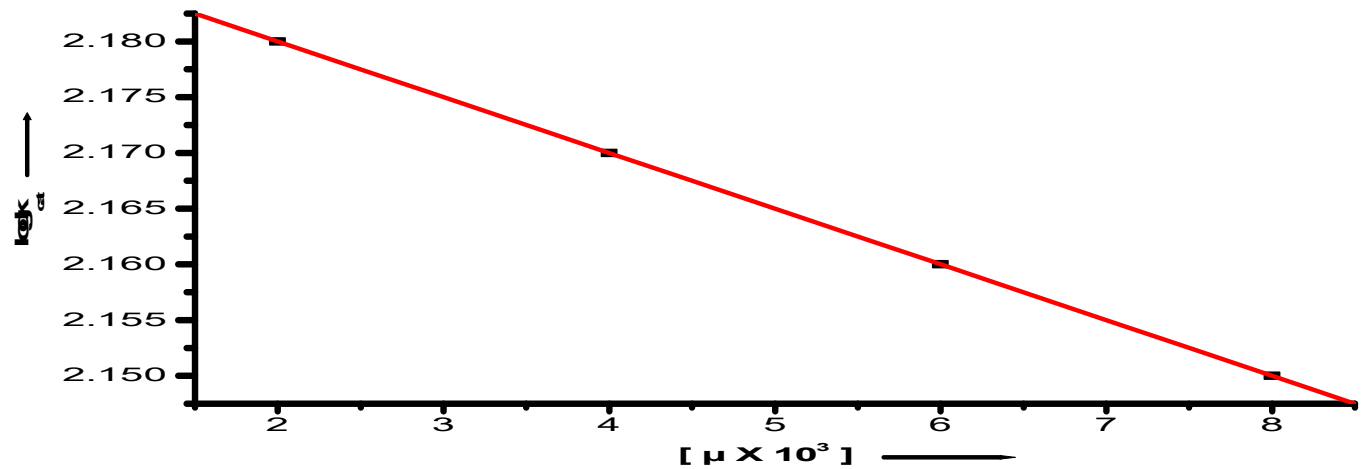

Fig.-10: Effect of Ionic Strength (log $k_{\text {cat }}$ Vs Ionic Strength)

Condition: $[\mathrm{OABAlc}] \times 10^{4}=4.0 \mathrm{M},[\mathrm{KPS}] \times 10^{3}=5.5 \mathrm{M},[\mathrm{Ag}(\mathrm{I})] \times 10^{4}=3.0 \mathrm{M},\left[\mathrm{NaNO}_{3}\right] \times 10^{3}=2.0$ to $8.0 \mathrm{M}$, Temp $=40 \pm 0.1^{\circ} \mathrm{C}, \mathrm{pH}=7.0, \lambda_{\max }=440 \mathrm{~nm}$

The plot of $\log k_{c a t}$ vs 1/D was found to be linear with and negative slope which reaffirms that the ratedetermining step is the reaction between a dipole and anion of persulphate. The dielectric constant (D) was calculated by the following formula:

$D=\left[\left(V_{\text {acetone }} \times D_{\text {acetone }}\right)+\left(V_{\text {water }} \times D_{\text {water }}\right)\right] /($ total volume of reaction mixture $)$

Where $\mathrm{V}_{\text {acetone }}=$ the volume of acetone in the reaction mixture, $\mathrm{D}_{\text {acetone }}=$ the dielectric constant of acetone at $40^{\circ} \mathrm{C}$ temperature. $V_{\text {water }}$ is the volume of water in the reaction mixture, and $D_{\text {water }}$ is the dielectric constant of water at $40^{\circ} \mathrm{C}$. The graph of dielectric constant with negative slope by plotting the graph between $\log k_{\text {cat }}$ and 1/D is shown in Fig.-11.

\section{Effect of Temperature}

For establishing the impact of varying temperatures on the rate of reaction, the reaction was carried in the temperature range of $40^{\circ} \mathrm{C}$ to $55^{\circ} \mathrm{C}$ at $\mathrm{pH} 7.0$. The presentation of data according to the Arrhenius equation is shown in Table-2.

The activation energy $\left(E_{a}\right)$ was found to be $58.92 \mathrm{~kJ} / \mathrm{mol}$, temperature coefficient (ח) as 1.99 , Arrhenius factor (A) as $9.19 \times 10^{11} \mathrm{dm}^{3} / \mathrm{mol}-\mathrm{s}$, activation entropy $\left(\Delta \mathrm{S}^{\#}\right)$ as $-53.61 \mathrm{~J} / \mathrm{k}-\mathrm{mol}$, activation enthalpy $\left(\Delta \mathrm{H}^{\#}\right)$ as $56.25 \mathrm{~kJ} / \mathrm{mol}$, and free energy of activation $\left(\Delta \mathrm{F}^{\#}\right)$ as $73.43 \mathrm{~kJ} / \mathrm{mol}$. Thereby by increasing the temperature of the reaction mixture, the rate of reaction increases. A plot of $\log k_{c a t} \mathrm{v} / \mathrm{s} 1 / \mathrm{T}$ was found to be linear, which indicates that the Arrhenius equation relating the temperature and specific rate with the 
RASĀYAN J. Chem.

98-109| Special Issue | 2021

equation- $\log k_{\text {cat }}=[-\mathrm{Ea} / 2.303 \mathrm{RT}]+$ Constant. The positive value of enthalpy of activation indicates that the reaction was endothermic ${ }^{34}$ and the negative value of entropy of activation shows that charged and rigid transition state was formed, which indicates the formation of product. The plot between $\log k_{c a t}$ and 1/T is shown in Fig.-12.

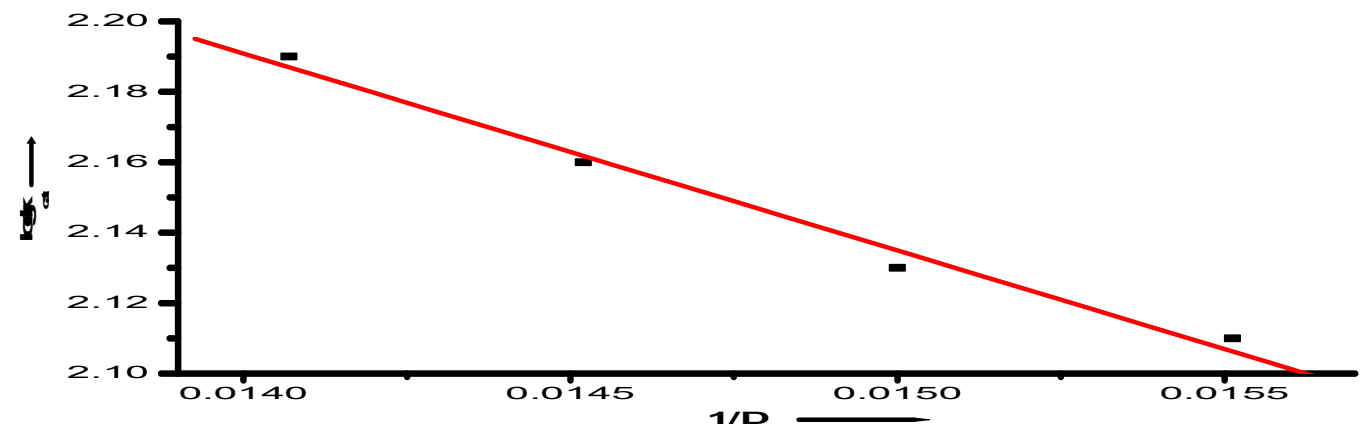

Fig.-11: Effect of Dielectric Constant on Reaction Rate

Condition: $[\mathrm{OABAlc}] \times 10^{4}=4.0 \mathrm{M},[\mathrm{KPS}] \times 10^{3}=5.0 \mathrm{M},[\mathrm{Ag}(\mathrm{I})] \times 10^{4}=3.0 \mathrm{M}, \mathrm{Temp}=40 \pm 0.1^{0} \mathrm{C}, \mathrm{pH}=7.0, \lambda_{\max }=$ $440 \mathrm{~nm}$.

Table-2: Thermodynamic Activation Parameters for Ag (I) catalysed Oxidation of OABAlc by Potassium

Persulphate in Ammonia Buffer Medium at $40^{\circ} \mathrm{C}$

\begin{tabular}{cc|ccccccc}
\hline $\begin{array}{c}\text { Temp. } \\
\left({ }^{0} \mathrm{C}\right)\end{array}$ & $\begin{array}{l}k_{\text {cat }} \times 10^{-2} \\
\mathrm{dm}^{6} \mathrm{~mol}^{-}\end{array}$ & $\begin{array}{c}\mathrm{E}_{\mathrm{a}} \\
(\mathrm{kJ} / \mathrm{mol})\end{array}$ & $\begin{array}{c}\text { Temp. } \\
\text { coefficient }\end{array}$ & $\begin{array}{c}\mathrm{A} \times 10^{11} \\
\left(\mathrm{dm}^{3} / \mathrm{mol}-\mathrm{s}\right)\end{array}$ & $\begin{array}{c}-\Delta \mathrm{S}^{\#} \\
\mathrm{~J} / \mathrm{k}-\mathrm{mol}\end{array}$ & \multicolumn{2}{c}{$\begin{array}{c}\Delta \mathrm{H}^{\#} \\
(\mathrm{~kJ} / \mathrm{mol})\end{array}$} & \multicolumn{1}{c}{$\begin{array}{c}\Delta \mathrm{F}^{\#} \\
(\mathrm{~kJ} / \mathrm{mol})\end{array}$} \\
\hline $40^{0} \mathrm{C}$ & 1.35 & - & - & 9.150083852 & 50.02268754 & 56.31333803 & 73.03025832 \\
\hline $45^{0} \mathrm{C}$ & 1.95 & 60.86843586 & - & 9.258678631 & 52.44584520 & 56.27176999 & 73.29829783 \\
\hline $50^{0} \mathrm{C}$ & 2.75 & 58.72152793 & 2.03703704 & 9.248170920 & 54.81884448 & 56.23020195 & 73.56633734 \\
\hline $55^{0} \mathrm{C}$ & 3.79 & 58.15652829 & 1.94358974 & 9.123005278 & 57.14421851 & 56.18863391 & 73.83437680 \\
\hline $\begin{array}{c}\text { Mean } \\
\text { Values }\end{array}$ & & 58.91549733 & 1.99031339 & 9.194984673 & 53.60789894 & 56.25098597 & 73.43231758 \\
\hline
\end{tabular}

Where $E_{a}=$ activation energy, $A=$ frequency factor, $\Delta \mathrm{S}^{\#}=$ activation enthalpy; $\Delta \mathrm{H}^{\#}=$ activation entropy, $\Delta \mathrm{F}^{\#}=$ free energy.

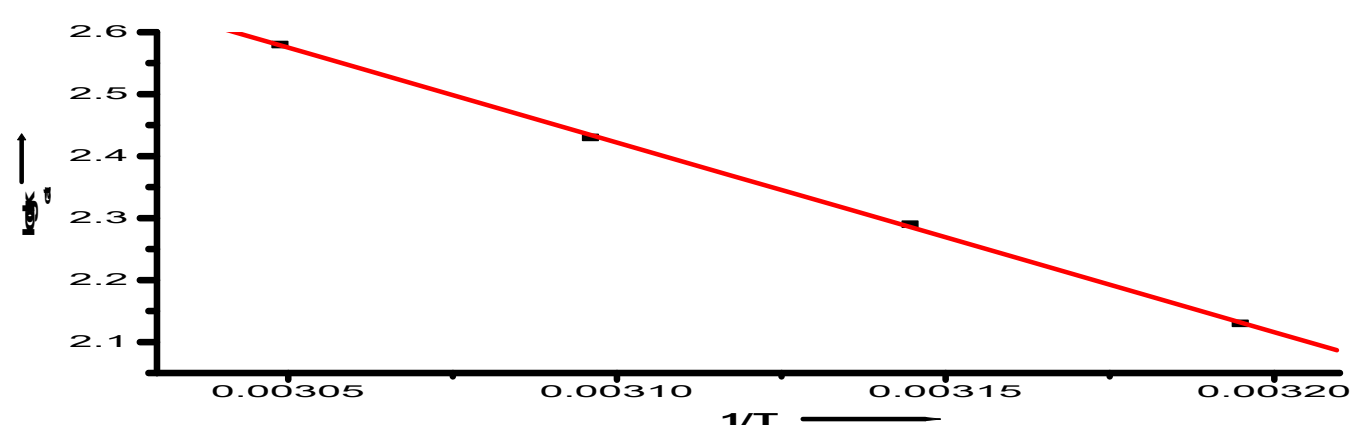

Fig.-12: Arrhenius plot

Conditions: $[\mathrm{OABAlc}] \times 10^{4}=4.0 \mathrm{M},[\mathrm{KPS}] \times 10^{3}=4.0 \mathrm{M},[\mathrm{Ag}(\mathrm{I})] \times 10^{4}=3.0 \mathrm{M}, \mathrm{pH}=7.0, \lambda_{\max }=440 \mathrm{~nm}$

\section{CONCLUSION}

A cost-effective way to monitor and remove OABAlc from a contaminated sample of water through oxidation is being pursued to develop a comprehensive method by carrying out the reaction under varied conditions of $\mathrm{pH}$, ionic strength, temperature, and dielectric constant alongside the variation in concentration of substrate, oxidant, and catalyst for a meticulous approach. The study has shown that the reaction can be easily executed under normal conditions of temperature, $\mathrm{pH}$ with moderate quantities of reagents and instruments been involved as well. Further studies to elucidate the mechanism of the reaction and also to understand the dynamics involved in this reaction are underway. 
RASĀYAN J. Chem.

98-109| Special Issue | 2021

\section{REFERENCES}

1. H. Goksu and F. Sen, Scientific Reports, 10, 5731(2020), https://doi.org/10.1038/s41598-020-626954

2. H. Goksu, H. Burhan, S. D. Mustafov and F. Sen, Scientific Reports, 10(1), 5439(2020), https://doi.org/10.1038/s41598-020-62400-5

3. N. Zotova, K. Hellgardt, G. H. Kelsall, A. S. Jessiman and K. K. M. Hii, Green Chemistry, 12, 2157(2010), https://doi.org/10.1039/C0GC00493F

4. A. Kumar, P. K. Sharma and K. K. Banerji, Journal of Physical Organic Chemistry, 15(10), 721(2002), https://doi.org/10.1002/poc.541

5. B. L. Ryland and S. S. Stahl, A Journal of German Chemical Society, 53(34), 8824(2014), https://doi.org/10.1002/anie.201403110

6. C. B. R. Reddy, S. R. Reddy and S. Naidu, Chemistry Open Communication, 4(2), 107(2014), https://doi.org/10.1002/open.201402082

7. Q. Cao, L. M. Dornan, L. Rogan, N. L. Hughes and M. J. Muldoon, Catalysis Science \& Technology, 4(6), 1720(2014), https://doi.org/10.1039/C4CY00219A

8. T. Punniyamurthy, S. Velusamy and J. Iqbal, Chemical Reviews, 105(6), 2329(2005), https://doi.org/10.1021/cr050523v

9. I. W. C. E. Arends and R. A. Sheldon, 2010, Modern Oxidation of Alcohols using Environmentally Benign Oxidants, Wiley-VCH Verlag, p. 147-185, https://doi.org/10.1002/9783527632039.ch5

10. Z. Tang, J. Tan, L. Cai, X. Li and W. Liu, Chinese Journal of Applied Chemistry, 34(3), 345(2017)

11. A. Widodo, P. Widiyanti and B. Prajogo, African Journal of Infectious Diseases, 12, 36(2018)

12. H. D. Bendorf, E. N. Vebrisky and B. J. Eck, Journal of Chemical Education, 93(9), 1637(2016), https://doi.org/10.1021/acs.jchemed.6b00155

13. H. S. Nalwa, M. Suzuki and A. Takahashi, Applied Physics Letters, 72, 1311(1998), https://doi.org/10.1063/1.121683

14. H. V. Mierde, P. V. D. Voort and F. Verpoort, Tetrahedron Letters, 49(48), 6893(2008), https://doi.org/10.1016/j.tetlet.2008.09.103

15. K. Ebitani, K. Motokura, T. Mizugaki and K. Kaneda, A Journal of German Chemical Society, 44(22), 3489(2005), https://doi.org/10.1002/anie.200462600

16. T. Kosjek, E. Heath, S. Pérez, M. Petrović and D. Barceló, Journal of Hydrology, 372, 109(2009), https://doi.org/10.1016/j.jhydrol.2009.04.006

17. C. S. Cho, B. T. Kim, T. J. Kim and S. C. Shim, Chemical Communication, 24, 2576(2001), https://doi.org/10.1039/B109245F

18. C. S. Cho, B. T. Kim, H. J. Choi, T. J. Kim and S. C. Shim, Tetrahedron, 59(40), 7997(2003), https://doi.org/10.1016/j.tet.2003.08.027

19. C. S. Cho, W. X. Ren and S. C. Shim, Bulletin of the Korean Chemical Society, 26(12), 2038(2005), https://doi.org/10.5012/bkcs.2005.26.12.2038

20. C. S. Cho, W. X. Ren and S. C. Shim, Bulletin of the Korean Chemical Society, 26(8), 1286(2005), https://doi.org/10.5012/bkcs.2005.26.8.1286

21. K. Taguchi, S. Sakaguchi and Y. Ishii, Tetrahedron Letters, 46(27), 4539(2005), https://doi.org/10.1016/j.tetlet.2005.05.013

22. K. Wang, H. Chen, X. Dai, X. Huang, and Z. Feng, Royal Society of Chemistry, 11,13119(2021), https://doi.org/10.1039/D1RA01755A

23. C. S. Cho, H. J. Seok and S. O. Shim, Journal of Heterocyclic Chemistry, 42(6), 1219(2005), https://doi.org/10.1002/jhet.5570420630

24. C. S. Cho, W. X. Ren and S. C. Shim, Tetrahedron Letters, 47(38), 6781(2006), https://doi.org/10.1016/j.tetlet.2006.07.067

25. K. Gopalaiah, A. Saini and A. Devi, Organic \& Biomolecular Chemistry, 15(27), 5781(2017), https://doi.org/10.1039/C7OB01159H

26. W. Nabeyama, K. Ishihara, H. S. Ban, H. Wada and H. Nakamura, Bioorganic \& Medicinal Chemistry, 25(9), 2601(2017), https://doi.org/10.1016/j.bmc.2017.03.024 
RASĀYAN J. Chem.

98-109| Special Issue | 2021

27. J. Lee, U. v. Gunten and J. H. Kim, Environmental Science \& Technology, 54, 3064(2020), https://doi.org/10.1021/acs.est.9b07082

28. L. W. Matzek and K. E. Carter, Chemosphere, 151, 178(2016), https://doi.org/10.1016/j.chemosphere.2016.02.055

29. C. Liang, Y. Y. Guo, Y. C. Chien and Y. J. Wu, Industrial \& Engineering Chemistry Research, 49(18), 8858(2010), https://doi.org/10.1021/ie100740d

30. E. A. Guggenheium, Philosophical Magazine, 2(9), 538(1926), https://doi.org/10.1080/14786442608564083

31. K. S. Gupta, P. Bhargava and S. V. Manoj, Transition Metal Chemistry, 26, 71(2001), https://doi.org/10.1023/A:1007195721986

32. P. Sharma, R. Sailani, D. Pareek and C. L. Khandelwal, Turkish Journal of Chemistry, 42, 158(2018). http://dx.doi.org/10.3906/kim-2003-67 (Available from https://journals.tubitak.gov.tr/chem/issues/kim-18-42-1/kim-42-1-14-1701-32.pdf)

33. A. Kumar, Pelagia Research Library, 5(1), 39(2014)

34. Manila, R. D. Kaushik, N. Bhatt, J. Singh, A. Pal and S. Sharma, Rasayan Journal of Chemistry, 13(3), 1424(2020), http://dx.doi.org/10.31788/RJC.2020.1335771

[RJC-6566/2021] 